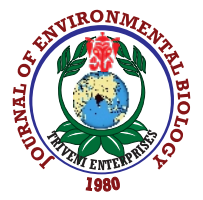

\title{
Microbial induction of resistance in tomato against root-knot nematode Meloidogyne javanica with biocontrol agents
}

\author{
Y.S.A. Mazrou ${ }^{1,2}$, A.H. Makhlouf ${ }^{3}$, M.M. Hassan ${ }^{4,5}$, A. Baazeem ${ }^{5}$ and M.M. Hassan ${ }^{5,6 *}$ \\ ${ }^{1}$ Department of Business Administration, Community College, King Khaled University, 62529, Kingdom of Saudi Arabia \\ ${ }^{2}$ Department of Agricultural Economics, Faculty of Agriculture, Tanta University, 3111, Egypt \\ ${ }^{3}$ Department of Botany, Faculty of Agriculture, Menoufia University, 32514, Egypt \\ ${ }^{4}$ Zoology Department, Faculty of Science, Ain Shams University, 11566, Egypt \\ ${ }^{5}$ Department of Biology, Faculty of Science, Taif University, 21944, Saudi Arabia \\ ${ }^{6}$ Department of Genetics, Faculty of Agriculture, Menoufia University, 32514, Egypt \\ *Corresponding Author Email : khyate_99@yahoo.com, m.khyate@tu.edu.sa
}

\section{Abstract}

Aim: To investigate the effect of some bacterial and algal strains on induction of resistance against root-knot nematode (Meloidogyne javanica) in tomato (Solanum lycopersicum L.) roots.

Methodology: Application of Bacillus subtilis, Serratia marcescens, and Spirulina platensis on root area of nematode infected tomato plant, the number invading nematode, $M$. javanica, galls and egg masses in tomato roots were determined.

Results: The reduction percentage $(94.97 \%)$ of developmental stages of root-knot nematode was highest in S. platensis treatment, among the biological agents and compared to $97.48 \%$ in chemical pesticide Vydate treatment. The highest reduction percentage $(90.43 \%)$ in female numbers was recorded with $B$. subtilis. All tested bioagents significantly increased vegetative weight of tomato plants. B. subtilis, S. marcescens and S. platensis increased the activity of peroxidase, polyphenol oxidase, superoxide dismutase and catalase in tomato plants infected with M. javanica.

Interpretation: Biological control of nematodes using alga and bacteria that could potentially enhance plant health, productivity and promotes its growth.

Key words: Bacillus subtilis, Biological control, Root-knot nematode, Serratia marcescens, Spirulina platensis,

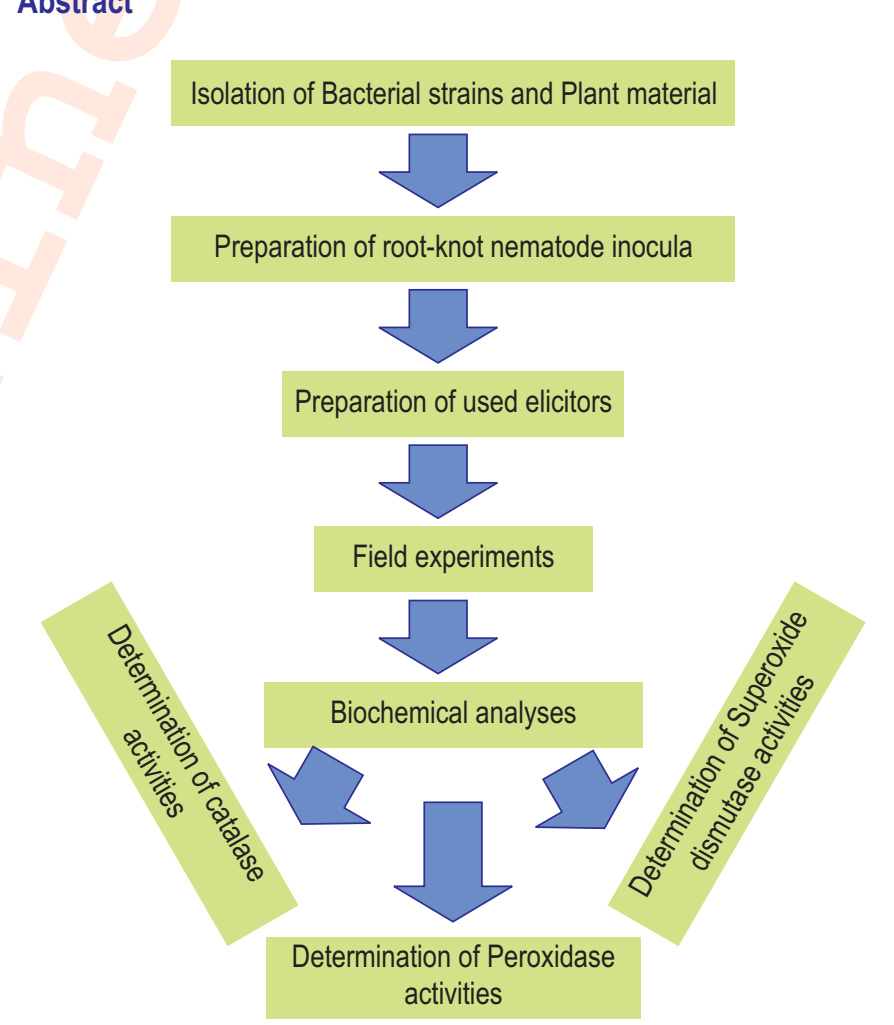

How to cite : Mazrou, Y.S.A., A.H. Makhlouf, M.M. Hassan, A. Baazeem and M.M. Hassan: Microbial induction of resistance in tomato against root-knot nematode Meloidogyne javanica with biocontrol agents. J. Environ. Biol., 41, 1054-1060 (2020). 


\section{Introduction}

Root-knot nematodes, Meloidogyne spp. are considered the most serious pathogens to be causing $5 \%$ loss to all economic crops of the world (Jones et al., 2013). 10\% of all nematode species are plant parasites, $50 \%$ are free living species that feed on other organisms in marine water, $25 \%$ of nematodes inhabit freshwater or soil, and $15 \%$ are zoo parasitic (Adam et al., 2014). Approximately, two thousand plant species have been registered as host to root-knot nematodes, and most of cultivated crops are attacked by at least one root-knot nematode specie (AbdElgawad and Askary, 2018). Root knot nematode is one of the major pathogens of tomato worldwide, causing stunt in growth and decrease in fruit production (Sikora and Fernandez, 2005). The use of chemical nematicides has been the main agents to control plant parasitic nematodes over the past five decades (Dela et al., 2014). However, due to the adverse environmental impacts associated with application of chemicals in agriculture directed the researchers to use safe methods for biological control of parasitic nematode (Dela et al., 2014;Abd-Elgawad et al., 2010; Gawade et al., 2017).

Several biological control strategies, such as host plant resistance, rotation with non-hosts, drainage and avoidance, destruction of residual crop roots, and wise use of nematicides, are considered as effective means for controlling root knot nematode (Abd-Elgawad etal., 2010; Elhady et al., 2017).

Induced resistance is accomplished by the inoculating plant with a mild virulent or non-pathogenic isolate (Topalović, and Heuer, 2019). Plant growth promoting rhizobacteria (PGPR) is considered as an alternative method to biological control and promoted plant growth (Cao et al., 2015; Cordovez et al., 2018). The potentiality of PGPR in agriculture is steadily increased as it offers an attractive way to replace the use of chemical fertilizers, pesticides and other supplements. Growth promoting substances are likely to be produced in large quantities by these rhizosphere microorganisms that indirectly influence the overall morphology and health of the plants.

Rhizobacteria eliminate parasitic nematodes through induction of plant systemic resistance (Hasky-Gunther et al., 1998), change nematode behavior (Bhattacharyya and Jha, 2012) and activating plant growth (El-Nagdiand Youssef, 2004; Karlidag et al., 2007). Additionally, cyanobacteria or blue-green algae produce large number of compounds with various biochemical activities. Holajer et al. (2013) demonstrated that were used as test plants, cyanobacterial extracts inhibit hatching and induce immobility and mortality in plant parasite nematodes; moreover, its use in soil may decrease nematode infection and increase plant productivity.

In view of the above, the present study was undertaken to investigate the effect of bio-control agents like Bacillus subtilis,
Serratia marcescens, and Spirulina platensis on, Meloidogyne spp., a root knot nematode infecting tomato roots.

\section{Materials and Methods}

Bacteria and algal strains source, preparation, inducers and elicitors : Two bacterial strains, Bacillus subtilis, Serratia marcescens and cyanobacterial strain, Spirulina platensis were selected as bio-control agents and were obtained from Agricultural Gene Bank, Ain Shams University, Egypt and cultured on Zarrouk medium (Nikoo, 2014). Bacterial strains were isolated the rhizosphere healthy tomato plants Menoufia University Farm and identified using 16S rDNA according to Hassan and Ismail, (2014) (Data not show). Cyanobacterial strain was also obtained from the Agricultural Gene Bank, Ain Shams University, Egypt and cultured on Zarrouk medium (Nikoo, 2014). Vydate 24\% L.; methyl 2-(dimethylamino)-N-(methyl carbamoyloxy)-2-oxoethanimidothioate (DuPont ${ }^{\mathrm{TM}}$ Vydate $囚$ ) a nematicide and insecticide of group $1 \mathrm{~A}$ organocarbamates was used chemical treatment. Four-week-old tomato seedlings (Solanum lycopersicum. cv. Beto) were

The culture of Meloidogyne javanica was prepared from a single egg mass of adult female and identified by the morphological characteristics of female perineal pattern as described by Taylor and Sasser (1978). Eggs of nematodes were extracted from identified tomato roots using $0.5 \%$ sodium hypochlorite (Hussey and Barker, 1973). Roots were cut into small pieces and macerated for $10 \mathrm{sec}$ with a electric blender, shaken for three min to release eggs from the gelatinous matrix. Eggs were collected on the sieve ( 400 mesh) and washed several times with tap water to remove the residual of $\mathrm{NaOCl}$, and transferred to a flask in tap water for counting. Root-knot nematode was applied by adding aqueous suspension of approximately 2000 eggs around the rootzone.

Greenhouse experiment: Five tomato seedlings were planted in a $20 \mathrm{~cm}$ diameter plastic pots filled with autoclaved sandy loam soil (1:1). Biotic elicitors (Bacillus subtilis, Serratia marcescens, and Spirulina platensis) ( $\left.5 \mathrm{ml}^{\circ} 10^{9} \mathrm{CFU} \mathrm{m}^{-1}\right)$ were added at the time of planting. All pots were inoculated with nematode by adding aqueous suspension of approximately 2000 eggs around the root zone and left until the end of experiments. Control was treated only with 2000 eggs of $M$. javanica, furthermore five tomato pots without nematode were used for more confirmation. Five replicates of each treatment were prepared. Experiment was designed in a complete randomized block and kept in the greenhouse at $25 \pm 5^{\circ} \mathrm{C}$, pots were irrigated, and fertilized when required. Seventy days after nematode inoculation, tomato plants were carefully uprooted. Roots were washed by water and stained in phloxine B stain; Root knot nematode galls and egg masses were extracted and counted per gram root weight. Reduction percentage of root knot nematode stages, galls and egg masses was calculated. 
Nematode stages extraction and counting: Egg masses of $M$. javanica were stained by dipping the root system in phloxine $B$ solution (0.15 g l-1 tap water) for 20 min (Daykin and Hussey, 1985). Phloxine B primarily stains the gelatinous egg-mass and naked viable eggs were counted. Roots from each replicate were placed in hot acid fuchsin lactophenol, at least for $24 \mathrm{hr}$, then transferred to Petri dish and examined under dissecting microscope for counting the developing stages and females of $M$. javanica. Soil sample of $200 \mathrm{~cm}^{3}$ of each treatment were processed to nematode extraction in modified Baermann funnels for $72 \mathrm{hrs}$. Second stage juveniles of $M$. javanica were counted using Hawksely counting slide under dissecting stereomicroscope. The length and weight of dry shoots and roots each plant were measured from each treatment.

Biochemical analyses: Terminal buds in addition to first and second young leaves were used for estimation of peroxidase, polyphenol oxidase, superoxide dismutase and catalase activities. In this regard, $2 \mathrm{~g}$ of plant materials were homogenized with $10 \mathrm{ml}$ of phosphate buffer ( $\mathrm{pH} \mathrm{6.8)}$, then centrifuge at $2^{\circ} \mathrm{C}$ for $20 \mathrm{~min}$ at $20000 \mathrm{rpm}$ in a refrigerated centrifuge. The clear supernatant (containing enzymes) was taken as the source of enzymes (Misra and Fridovich, 1972).

Peroxidase activity was assayed by using solution containing $5.8 \mathrm{ml}$ of $50 \mathrm{mM}$ phosphate buffer (pH 7), $0.2 \mathrm{ml}$ of enzyme extract and $2 \mathrm{ml}$ of $20 \mathrm{mMH}_{2} \mathrm{O}_{2}$ after adding $2 \mathrm{ml}$ of $20 \mathrm{mM}$ pyrogallol, the rate of increase in absorbance as pyrogallol was determined spectrophotometrically within $60 \mathrm{sec}$ at $470 \mathrm{~nm}$ and $25^{\circ} \mathrm{C}$ (Bergmeyer, 1974). One unit of enzyme activity was defined as the amount of enzyme that catalyzed the conversion of one micromole of $\mathrm{H}_{2} \mathrm{O}_{2}$ per minute at $25^{\circ} \mathrm{C}$ (Kong etal., 1999).

Polyphenoloxidase activity was assayed using $125 \mu \mathrm{mol}$. of phosphate buffer (pH 6.8), $100 \mu \mathrm{mol}$ pyrogallol and $2 \mathrm{ml}$ of enzyme extract according to Kar and Mishra (1976). Boiled enzyme extract was used as blank sample, the color was measured at $430 \mathrm{~nm}$ and enzyme activity was measured as change in the optical density $g^{-1} \mathrm{f}$. wt. $\mathrm{hr}^{-1}$.

The activity of superoxide dismutase was measured by the inhibition degree of auto-oxidation of pyrogallol according to Marklund and Marklund (1974). A unit of enzyme activity is the amount of enzyme that results in $50 \%$ inhibition of auto-oxidation rate of pyrogallol at $25^{\circ} \mathrm{C}$ (Kong et al., 1999).

Catalase activity was assayed according to Chen et al. (2000). Catalase activity is equal to the change in hate of $\mathrm{H}_{2} \mathrm{O}_{2}$ absorbance in $60 \mathrm{sec}$ with a UV- spectrophotometer at $250 \mathrm{~nm}$. A unit of enzyme activity is equal to the amount of enzyme that reduces $50 \%$ of $\mathrm{H}_{2} \mathrm{O}_{2}$ in $60 \mathrm{sec}$ at $25^{\circ} \mathrm{C}$ (Kong et al., 1999).

To assay the enzyme, volume at zero time was considered as blank and the activity of enzyme was calculated by the equation: $(\Delta \times T \vee \times 60 \mathrm{~min}) /(\mathrm{t} \times \mathrm{v} \times \mathrm{f}$.wt.), where $\Delta$ is the absorbance of the sample after incubation minus that at zero time; $T v$ is the total volume of filtrate; $t$ is the time (min.) of incubation with substrate and $v$ is the volume of filtrate used for incubation (Fick and Qualset, 1975).

Statistical analysis: The difference between means of studied treatments were tested by ANOVA at $5 \%$ probability level. A post hoc (Duncan 's Multiple Range and LSD) Tests was applied using CoStat software program (Version 6.400).

\section{Results and Discussion}

Root-knot nematodes are dangerous pest for many economic crops. (Abd-Elgawad and Askary, 2018). Biological control of plant parasitic nematodes is the best choice for human health and safe environment (Gawade et al., 2017). Nematophagous fungi and bacteria are widely used among the nematode-antagonistic organisms (Askary and Martinelli, 2015); where they include tolerant genera to sun heat, desiccation and are not influenced by the regular use of agricultural chemicals (Adam et al., 2014; Stevens and Lewis 2017; Topalović and Heuer, 2019). In the present study, application of bio-control agents, B. subtilis, S. marcescens and S. platensis significantly decreased the number of $M$. javanica and galls in tomato roots (Table 1). Statistical analysis showed significant differences in gall numbers between all treatments (5-48 galls) as compared to the control (87 galls). Reduction percentages in root gall numbers were highest (94.25\%) in Vydate treatment, followed by $79.31 \%$ in B. subtilis and $68.97 \%$ in S. platensis treatment, while it was only $44.83 \%$ in $S$. marcescens treatment, respectively. The number of egg masses significantly varied among all treatments (1-15) compared to control (50). The highest percentage was recorded in Vydate pesticide (98\%), followed by $84 \%$ in B. subtilis, $76 \%$ in S. platensis and $70 \%$ in S. marcescens treatments. There are different modes of action of bacteria against plant parasitic nematodes. The microbial control of nematode plant parasites include gelatinase, protease and chitinase activities that affect nematodes (Bahloul, 2013). Some nematophagous mycelial endospore-forming bacteria of genus Bacillus have protease genes and can infect nematodes by adhering their spores to nematode cuticle (Tian et al., 2007). B. subtilis has genes producing antibiotics such as surfactin and iturin, however, $S$. marcescens produces toxic metabolites that affect parasitic nematodes (Abd-Elgawad and Askary, 2018). Bacillus is considered as plant growth promoting rhizobacteria and microbial control agent for nematodes (Dong and Zhang, 2006).

The root gall index was highest with $S$. marcescens followed by in B. subtilis and S. platensis treatments as compared to the control. On the other side, egg mass index was 3.0 with $S$. marcescens and $S$. platensis and 2.0 with $B$. subtilis treatments as compared to the control (4.0). The effect of $B$. subtilis, $S$. 
Table 1 : Effect of B. subtilis, S. marcescens, and S. platensis on galls and egg-masses of M. javanica infecting tomato plants under greenhouse conditions

\begin{tabular}{lllllll}
\hline Treatments & $\begin{array}{l}\text { Average number } \\
\text { of galls } \text { g }^{-1} \text { roots }\end{array}$ & Reduction \% & Root gall index & $\begin{array}{l}\text { Average number of } \\
\text { egg mass g }{ }^{-1} \text { roots }\end{array}$ & $\begin{array}{l}\text { Reduction \% } \\
\text { Egg mass } \\
\text { index }^{*}\end{array}$ \\
\hline B. subtilis & $18.0^{\mathrm{d}}$ & 79.31 & 3 & $8.0^{\mathrm{c}}$ & 84.0 & 2 \\
S. marcescens & $48.0^{\mathrm{b}}$ & 44.83 & 4 & $15.0^{\mathrm{b}}$ & 70.0 & 3 \\
S. platensis & $29.0^{\mathrm{C}}$ & 68.97 & 3 & $12.0^{\mathrm{bc}}$ & 76.0 & 3 \\
Vydate 24\%L & $5.0^{\mathrm{e}}$ & 94.25 & 2 & $1.0^{\mathrm{d}}$ & 98.0 & 1 \\
Control (Nematode only) & $87.0^{\mathrm{a}}$ & - & 5 & $50.0^{\mathrm{a}}$ & - & 4 \\
LSD5\% & 9.4 & - & - & 5.0 & - & - \\
\hline
\end{tabular}

*where $0=$ no galls or egg masses; $1=1$ to $2 ; 2=3$ to $10 ; 3=11$ to $30 ; 4=31$ to 100 ; and $5=$ more than 100 galls or egg masses (Taylor and Sasser, 1978)

Table 2: Effect of B. subtilis, S. marcescens, and S. platensis on different stages of $M$. javanica infecting tomato plants under greenhouse conditions

\begin{tabular}{|c|c|c|c|c|c|c|}
\hline \multirow[t]{2}{*}{ Treatments } & \multicolumn{2}{|c|}{ Second stage juveniles $250 \mathrm{~g}^{-1}$ soil } & \multicolumn{2}{|c|}{ Developmental stages $\mathrm{g}^{-1}$ root } & \multicolumn{2}{|c|}{ Females $\mathrm{g}^{-1}$ root } \\
\hline & Average number & Reduction \% & Average numbers & Reduction \% & Average numbers & Reduction \% \\
\hline B. subtilis & $89.0^{d}$ & 80.31 & $10.0^{\mathrm{c}}$ & 93.71 & $9.0^{\mathrm{C}}$ & 90.43 \\
\hline S.marcescens & $188.0^{b}$ & 58.41 & $12.0^{\mathrm{b}}$ & 92.45 & $17.0^{\mathrm{b}}$ & 81.91 \\
\hline S. platensis & $142.0^{\circ}$ & 68.58 & $8.0^{b c}$ & 94.97 & $14.0^{\mathrm{bc}}$ & 85.11 \\
\hline Vydate $24 \% \mathrm{~L}$ & $25.0^{\mathrm{e}}$ & 94.47 & $4.0^{\mathrm{d}}$ & 97.48 & $2.0^{d}$ & 97.87 \\
\hline Control (Nematode only) & $452.0^{\mathrm{a}}$ & - & $159.0^{\mathrm{a}}$ & - & $94.0^{\mathrm{a}}$ & - \\
\hline LSD $5 \%$ & 27.1 & - & 2.4 & - & 5.8 & - \\
\hline
\end{tabular}

marcescens and S. platensis on different stages of M. javanica infecting tomato plants under greenhouse conditions is shown in Table 2. As compared to control, the number of second stage juveniles were as follows: 188 individuals in S. marcescens, 142 individuals in $S$. platensis and 89 individuals in B. subtilis treatments respectively.

Percentage of second stage juveniles of root knot nematode was highly reduced (80.31\%) in B. subtilis, $68.58 \%$ in S. platensis, $58.41 \%$ in S. marcescens and $94.47 \%$ in Vydate pesticide treatments. The number of developmental stages of root knot nematode significantly varied among tested materials and control; the lowest number of individuals was recorded in $S$. platensis (8.0), followed by B. subtilis (10.0) and S. marcescens (12.0) treatments as compared to control (150.0). The highest reduction percentage of developmental stages of root knot nematode was recorded in S. platensis (94.97\%), followed by $B$. subtilis $93.71 \%$, S. marcescens $92.45 \%$ and Vydate pesticide $97.48 \%$ treatments. This could be due to the toxic metabolites produced by the bacteria (Abd-Elgawad and Askary, 2018) or endospores that attach to the cuticle of second stage juvenile (Tian et al., 2007), however, vydate acts as cholinesterase inhibitor for nematodes (Kesba and Al-Shalaby, 2008).

The number of root knot nematode females per gram root differed significantly between different materials and control. It was 17 females in S. marcescens, 14 females in S. platensis and
9 females in B. subtilis treatments as compared to 94 females in control. The highest reduction percentage in female number was recorded in B. subtilis $(90.43 \%)$, followed by $S$. platensis $(85.11 \%)$, S. marcescens treatments $(81.91 \%)$. The effect of $B$. subtilis, $S$. marcescens, and $S$. platensis treatments on vegetative weights of infected tomato plants showed significant differences in measurements between tested materials and control with or without nematodes (Table 3). The lowest decrease in percentage of shoot weight was recorded in S. platensis (14.2 $\%)$, followed by S. marcescens ( $25.8 \%$ ) and B. subtilis treatments (36.4\%) as compared to control (51.9\%) with nematode only. Regarding to root weight, the lowest decrease percentage was recorded in S. platensis (12.7\%), followed by S. marcescens $(22.8 \%)$ and B. subtilis (25.5\%) treatments as compared to the control $(44.9 \%)$ with nematode only. On the other side control without nematode recorded the highest dry shoot and root weights as it is not infected and with better nutrient intake leading to healthy growth.

The results of the present study on the effect of some bacterial strains and cyanobacteria on the number of $M$. javanica juveniles, their developmental stages and galls in tomato roots is in accordance with the reports Saad et al. (2010) who used biological control agents like Pseudomonas fluorescens, Trichoderma harzianum and their mixture. Mahfouz et al. (2010) used carbofuran, S. marcescens and three T. harzianum isolates; for controlling the population density of $M$. incognita infecting 
Table 3 : Effect of B. subtilis, S. marcescens and S. platensis on shoot and root weights of tomato plants infected with M. javanica under greenhouse conditions

\begin{tabular}{lllll}
\hline Treatment & Shoot dry weight $(\mathbf{g})$ & Percent decrease & Root dry weight $(\mathbf{g})$ & Percent decrease \\
\hline B. subtilis & $54.0^{\mathrm{d}}$ & 36.4 & $40.8^{\mathrm{c}}$ & 25.5 \\
S.marcescens & $63.0^{\mathrm{c}}$ & 25.8 & $42.3^{\mathrm{c}}$ & 22.8 \\
S. platensis & $72.8^{\mathrm{b}}$ & 14.2 & $47.8^{\mathrm{bc}}$ & 12.7 \\
Vydate 24\% & $78.8^{\mathrm{ab}}$ & 7.1 & $50.1^{\mathrm{ab}}$ & 8.6 \\
Control (Nematode only) & $40.8^{\mathrm{a}}$ & 51.9 & $30.2^{\mathrm{d}}$ & 44.9 \\
Check (No nematode) & $84.8^{\mathrm{a}}$ & - & $54.8^{\mathrm{a}}$ & - \\
LSD 5\% & 6.4 & - & $6.8^{\mathrm{a}}$ & - \\
\hline
\end{tabular}

Table 4 : Effect of B. subtilis, S. marcescens and S. platensis on the enzyme activity (unit $\mathrm{g}^{-1}$ f.wt. $\mathrm{hr}^{-1}$ ) of peroxidase, polyphenoloxidase, superoxide dismutase and catalase in tomato plants infected with $M$. javanica under greenhouse conditions

\begin{tabular}{lllll}
\hline Treatment & Peroxidase & Polyphenoloxidase & Superoxide-dismutase & Catalase \\
\hline B. subtilis & $5.24^{\mathrm{a}}$ & $1.46 \mathrm{~b}^{\mathrm{c}}$ & $2.81^{\mathrm{c}}$ & $1.21^{\mathrm{ab}}$ \\
S. marcescens & $5.17^{\mathrm{a}}$ & $1.78^{\mathrm{a}}$ & $2.92^{\mathrm{bc}}$ & $0.98^{\mathrm{bc}}$ \\
S. platensis & $4.03^{\mathrm{b}}$ & $1.67^{\mathrm{ab}}$ & $3.22^{\mathrm{ab}}$ & $0.87^{\mathrm{c}}$ \\
Vydate 24\% & $3.42^{\mathrm{c}}$ & $1.31^{\mathrm{d}}$ & $3.36^{\mathrm{a}}$ & $1.43^{\mathrm{a}}$ \\
Control (Nematode only) & $3.49^{\mathrm{c}}$ & $1.09^{\mathrm{d}}$ & $2.77^{\mathrm{c}}$ & $0.81^{\mathrm{c}}$ \\
Check (No nematode) & $1.57^{\mathrm{d}}$ & $0.73^{\mathrm{a}}$ & $0.81^{\mathrm{d}}$ & $0.12^{\mathrm{d}}$ \\
LSD 5\% & 0.24 & 0.25 & 0.32 & 0.23 \\
\hline
\end{tabular}

All values are means of unit $\mathrm{g}^{-1}$ fresh leaves per hour

tomatoes. All the treatments enhanced the plant growth of tomato and showed indirect effect on the length and weight of root and shoot systems, and significantly decreased the nematode population.

The efficiency of antagonistic effect of bacterial strains, B. subtilis, S. marcescens and Cyanobacterial strain S. platensis in reducing of root galls and egg masses (Cao et al., 2015; Sharaf et al., 2016b), and number of second juveniles in soil, females and developmental stages (Sharaf et al. 2016 a) of rootknot nematode, M. javanica infecting tomato roots have been reported. Some studies used coated crops seeds with bio-control agents like that used in the present study but it is expensive and not commercial option (Askary and Martinelli, 2015; Elhady et al., 2017), although it allows targeted delivery and potentially enhances rhizosphere colonization. Microbial seed treatment is used for controlling diseases and insects, and also for managing nematodes (Glare et al. 2012; Stevens and Lewis, 2017).

Statistical analysis of the obtained results of the inductive effects of $B$. subtilis, S. marcescens and S. platensis on the activity of peroxidase, polyphenoloxidase, superoxide dismutase and catalase in tomato plants, infected with M. javanica (Table 4) revealed significant differences between the values of these enzymes in the treated plants and control. Peroxidase enzyme displayed the highest increase percentage $(233.76 \%)$ in $B$. subtilis treatment, followed by $229.3 \%$ in S. marcescens, and
$156.69 \%$ in S. platensis treatments compared to $122.29 \%$ in control. The highest percentage for polyphenol oxidase enzyme was $143.84 \%$ in S. marcescens treatment, followed by $128.77 \%$ in S. platensis, and $156.69 \%$ in B. subtilis treatment compared to $49.32 \%$ in control with nematode only. Superoxide dismutase activity was highest S. marcescens treatment (620.49\%), followed by B. subtilis $246.91 \%$, and S. platensis (160\%) treatment as compared to control $241.98 \%$. The highest increase in catalase enzyme activity was $B$. subtilis $(908.33 \%)$ treatment, followed by S. marcescens (716.67 \%) and S. platensis (625\%) treatment as compared to control (575\%) with nematode only; however the lowest enzyme activities were found in control without nematode as there was no initiation or induction of oxidase enzymes due to lack of infection.

It was noticed that all tested bioagents significantly increased enzyme activities which were toxic for root-knot nematodes, as inducers to activate the resistance of tomato plants against the invading root-knot nematode. In addition, it was found that $S$. marcescens occupied the first rank in inducing plants to face pests, followed by B. subtilis and S. platensis. Sahebani and Hadavi (2009); Bhattacharyya and Jha (2012); and Elhady et al. (2017) obtained similar results for baminobutyric acid (BABA), salicylic acid (Hadis et al., 2014) and Pseudomonas fluorescens on the activity of superoxide dismutase, guaiacol peroxidase, and catalase in tomato roots infected with $M$. javanica. Plant-mediated systemic resistance 
against $M$. javanica in tomato by increasing the activity of their scavenging antioxidant enzymes, especially catalase using chemical and biological elicitors was carried out by Fatemeh et al. (2014) and against $M$. incognita using ten bacterial strains by Anter etal. (2014).

The results of this study suggests that use of chemicals for controlling parasitic nematodes should be replaced by environmental, safe bio-agents like: bacterial strains, Serratia marcescens and B. subtilis or algal strain, Spirulina platensis strain. Additionally, enzyme activities play a vital role as bioinducers to activate resistance in tomato plants against invading nematodes.

\section{Acknowledgment}

The authors extend their appreciation to the Deanship of Scientific Research at King Khalid University for funding this work through Program of Research Groups under grant number (R.G.P1/106/1440)

\section{References}

Abd-Elgawad, M.M. and S.A. Kabeil: Management of root-knot nematode, Meloidogyne incognita on tomato in Egypt. J. Amer. Sci., 6, 256-262 (2010).

Abd-Elgawad, M.M. and T.H. Askary: Fungal and bacterial nematicides in integrated nematode management strategies. Egypt J. Biol. Pest Con., 28, 74 (2018).

Adam, M., A. Westphal, J. Hallmann and H. Heuer: Specific microbial attachment to root knot nematodes in suppressive soil. Appl. Environ. Microbiol., 80, 2679-2686 (2014).

Anter, A.A., A.W. Amin, A.H. Ashoub and A.S. El-Nuby: Evaluation of some Rhizobacteria as induce systemic resistance or bio-control agents in controlling root-knot nematode, Meloidogyne incognita on tomato. Egypt J. Agronematol., 13, 107-123 (2014).

Askary, T.H. and P.R.P. Martinelli: Biocontrol agents of phytonematodes. CAB International, Wallingford, pp. 470 (2015).

Bergmeyer, H.U.: Methods of Enzymatic Analysis 1. $2^{\text {nd }}$ Edn., Academic Press, New York (1974).

Bhattacharyya, P.N. and D.K. Jha: Plant growth-promoting rhizobacteria (PGPR): Emergence in agriculture. World J. Microbiol. Biotechnol., 28, 1327-1350 (2012).

Cao, Y., B. Tian, X. Ji, S. Shang, C. Lu and K. Zhang:Associated bacteria of different life stages of Meloidogyne incognita using pyrosequencing-based analysis. J. Basic Microbiol., 55, 950-960 (2015).

Chen, C., R. Yu, E.D. Owuo and A.N. Kong: Activation of antioxidantresponse element (ARE), mitogen-activated protein kinases (MAPKs) and caspases by major green tea polyphenol components during cell survival and death. Arch. Pharm. Res., 23, 605-612 (2000).

Cordovez, V., S. Schop and K. Hordijk: Priming of plant growth promotion by volatiles of root-associated microbacterium. Appl. Environ. Microbiol., 73, 5639-5641 (2018).

Costat Version 6.400 Copyright $^{\circledR}(1998-2008)$ Cohort Software. 798 Lighthouse Ave. PMB 320, Monterey, CA, 93940, USA.

Daykin, M.E. and R.S. Hussey: Staining and histopathological techniques in nematology. In: An Advanced Treatise on Meloidogyne, Volume II: methodology (Eds.: K.R. Barker, C.C. Carter and J.N. Sasser). Raleigh, NC, USA, North Carolina State University Graphics, pp 39-48 (1985).

Dela, C., V. Bravo-Duran, F. Ramirez and L.E. Castillo: Environmental hazards associated with pesticide import into Costa Rica, 1977 2009. J. Environ. Biol., 35, 43-55 (2014).

Dong, L.Q. and K.Q. Zhang: Microbial control of plant-parasitic nematodes: a five-party interaction. Plant Soil, 288, 31-45 (2006).

Elhady, A., G. Ariadna and T. Olivera: Microbiomes associated with infective stages of root-knot and lesion nematodes in soil. PLOS ONE, 12, e0177145 (2017).

El-Nagdi, W.M.A. and M.M.A Youssef: Soaking faba bean seed in some bio-agent as prophylactic treatment for controlling Meloidogyne incognita root-knot nematode infection. J. Pest. Sci., 77, 75-78 (2004).

Fick, N.G. and C.O. Qualset: Genetic control of endosperm amylase activity: Gibberellin response in standard height and short saturated wheat. Proceedings of the National Academy of Sciences of the United States of America, 72, 892 (1975).

Gawade, B.H., A. Sirohi, A.K. Ganguly, R. Kansal, D. Choudhary and R. Koulagi: Effect of chickpea proteinase inhibitor on survival and parasitism of rootknot nematode, Meloidogyne incognita. J. Environ. Biol., 38, 347-352 (2017).

Glare, T.R., J. Caradus, W. Gelernter, T. Jackson and N. Keyhani: Have biopesticides come of age? Trends Biotech., 30, 250-258 (2012)

Hasky-Gunther, K., H.S. Hergarten and R.A. Sikora: Resistance against the potato cyst nematode Globodera pallida systematically induced by the rhizobacteria Agrobacterium radiobacter (G12) and Bacillus sphaericus (B43). Fund. Appl. Nematol., 21, 511-517 (1998).

Hassan, M.M. and A.I. Ismail: Isolation and molecular characterization of some pathogenic mobile phone bacteria. Int. J. Biochem. Biotechnol., 3, 516-522 (2014).

Holajjer, P., A. Kamra, H.S. Gaur and M. Manjunath: Potential of cyanobacteria for biorational management of plant parasitic nematodes: Areview. Crop Protec., 53,147-151 (2013).

Hussey, R.S. and K.R. Barker: A comparison of methods of collecting inocula of Meloidogyne spp. including a new technique. Plant Dis. Repor., 57, 1025-1028 (1973).

Jones, J.T., J.T. Jones, A. Haegeman and E.G. Danchin: Top 10 plantparasitic nematodes in molecular plant pathology. Mol. Plant Pathol., 14, 946-961 (2013).

Kar, M. and D. Mishra: Catalase, peroxidase and polyphenol oxidase activities during rice leaf senescence. Plant Physiol., 57, 315 (1976).

Karlidag, H., A. Esitken, M. Turan and F. Sahin: Effects of root inoculation of plant growth promoting rhizobacteria (PGPR) on yield, growth and nutrient element contents of leaves of apple. Sci. Hortic., 114, 16-20 (2007).

Kesba H.H. and M.E.M. Al-Shalaby: Survival and reproduction of Meloidogyne incognita on tomato as affected by humic acid. Nematology, 10, 243-249 (2008).

Kong, F.X., W. Hu, S.Y. Chao, W.L. Sang and L.S. Wang: Physiological responses of Mexicana to oxidative stress of $\mathrm{SO}_{2}$. Environ. Experim. Bot., 42, 201-209 (1999).

Marklund, S. and G. Marklund: Involvement of the superoxide anion radical in the autoxidation of pyrogallol and a convenient assay for superoxide dismutase. Eur. J. Biochem., 47, 469-474 (1974). 
Misra, H.P. and I. Fridovich: The role of superoxide anion in the autoxidation of epinephrine and a simple assay for superoxide dismutase. J. Biol. Chem., 247,3170-3175 (1972).

Mukherjee, S.P. and M.A. Choudhuri: Implication of water stress-induced changes in the level of endogenous ascorbic acid and hydrogen peroxide in Vigna seedlings. Physiol. Plant., 58, 166-170 (1983).

Nikoo, F.S., N. Sahebani, H. Aminian, L. Mokhtarnejad and R. Ghaderi: Induction of systemic resistance and defense-related enzymes in tomato plants using Pseudomonas fluorescens $\mathrm{CHAO}$ and salicylic acid against root-knot nematode Meloidogyne javanica. J. Plant Prot. Res., 54, 383-389 (2014).

Saad, A.S., M.A. Massoud, H.S. Ibrahim and M.S. Khalil: Nematocidal effect of biological control agents and other chemical compounds on Meloidogyne incognita infesting tomato plants. Alex. Sci. Exchange J., 31, 240-248 (2010).

Sahebani, N. and N. Hadavi: Induction of $\mathrm{H}_{2} \mathrm{O}_{2}$ and related enzymes in tomato roots infected with root knot nematode ( $M$. javanica) by several chemical and microbial elicitors. Biocont. Sci. Technol., 19, $301-313(2009)$

Sharaf, A.M.A., A.M. Kailla, M.S. Attia and M.M. Nofal: Evaluation of biotic and abiotic elicitors to control Meloidogyne incognita infecting tomato plants. Nat. Sci., 14, 125-137 (2016a).
Sharaf, A.M.A., A.M. Kailla, M.S. Attia and M.M. Nofal: Induced resistance in tomato plants against root knot nematode using biotic and abiotic inducers. Int. J. Advan. Res. Biol. Sci., 3, 31-46 (2016b).

Sikora, R.A. and E. Fernandez: Nematode parasites of vegetables. In: Plant parasitic nematodes in subtropical and tropical agriculture (Eds.: M. Luc, R.A. Sikora and J. Bridge). $2^{\text {nd }} E d n, C A B I$ Wallingford, UK. pp 319-392 (2005).

Stevens, G. and E. Lewis: Status of entomopathogenic nematodes in integrated pest management strategies in the USA. In: Biocontrol Agents: Entomopathogenic and Slug Parasitic Nematodes (Eds.: M.M.M. Abd-Elgawad, T. Askary and J. Coupland). CAB International, Wallingford, pp. 289-311 (2017).

Taylor, A.L. and J.N. Sasser: Identification and control of root-knot nematodes (Meloidogyne spp.) crop. Publ. Dep. Plant Pathol, North Carolina State University and U.S. Agency International Development Raliegh, N.C. pp. 111 (1978).

Tian, B., J. Yang and K. Zhang: Bacteria used in the biological control of plant-parasitic nematodes: Populations, mechanisms of action, and future prospects. FEMS Microbiol. Ecol., 61, 197-213 (2007).

Topalović, O. and $\mathrm{H}$. Heuer: Plant-nematode interactions assisted by microbes in the rhizosphere. Curr. Issues Mol. Biol., 30, 75-88 (2019). 